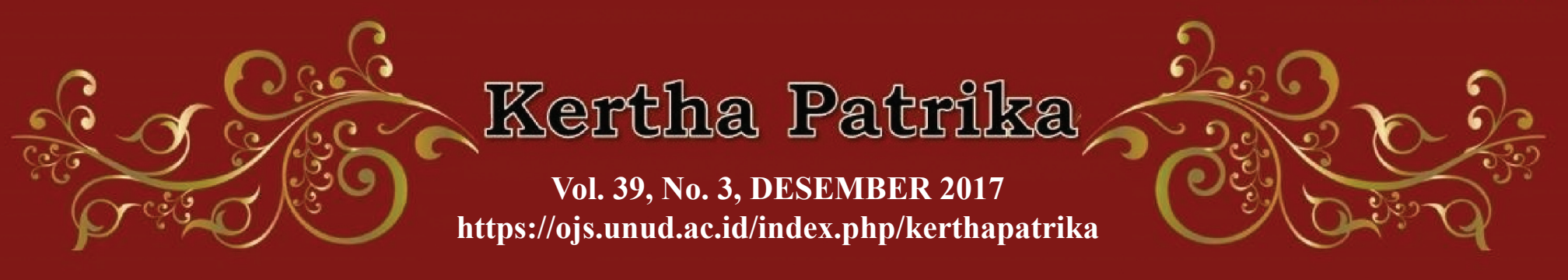

\title{
IMPLIKASI UNDANG-UNDANG NOMOR 4 TAHUN 2009 TENTANG PERTAMBANGAN MINERAL DAN BATUBARA DENGAN GREEN CONSTITUTION
}

Oleh :

\author{
Hudriyah Mundzir ${ }^{1}$
}

Politeknik Negeri Malang

\begin{abstract}
Abstrak
Indonesia merupakan salah satu negara di dunia yang mempunyai banyak sumber daya alam (natural resources) yang menjadikan kegiatan pertambangan sebagai salah satu aspek penggerak perekonomian di Indonesia. Dengan adanya Undang-Undang Nomor 4 tahun 2009 tentang Pertambangan Mineral dan Batubara memberi implikasi bagi keberlan $\neg$ jutan lingkungan hidup. Penelitian ini menggunakan metode penelitian hukum normatif, yaitu dengan meneliti pada data sekunder bidang hukum yang ada sebagai data kepustakaan. Penelitian ini menggunakan metode berpikir deduktif dan kriterium kebenaran koherenen. Pelitian ini bertujuan untuk mengkaji impikasi Undang-Undang Pertambangan Mineral dan Batubara dengan green constitution. Dari kajian dan pengolahan data menghasilkan sebuah konsep, yaitu perwujudan kedaulatan lingkungan (ecocracy).
\end{abstract}

Kata Kunci: Implikasi, Green Constitution, Kedaulatan Lingkungan (Ecocracy), Undang-undang Pertambangan Mineral dan Batubara.

Abstract

Indonesia is one of the countries in the world that has many natural resources that leads to a situation in which mining activities become a generating aspect of the Indonesian economy. The establishment of Law Number 4 Year 2009 concerning Mineral and Coal Mining has implication for environmental sustainability. This research uses normative legal research methods, by examining the existing secondary data as data library. It applies deductive thinking methods and criteria of coherent truth. This research aims to examine the implications of the Law on Mineral and Coal Mining from a green constitution perspective. The study and data analysis resulted in a concept, namely the realization of environmental sovereignty (ecocracy).

Keywords: Implication, Green Constitution, Environmental Sovereignity (Ecocracy), Mineral and Coal Mining Law.

DOI: 10.24843/KP.2017.v39.i03.p01

PENDAHULUAN

Wacana dan peristilahan "green constitution" adalah merupakan fenomena pada tahun 1970-an. Istilah green constitution adalah istilah yang sering dipakai untuk menggambarkan keterkaitan sesuatu dengan perlindungan lingkungan hidup. Istilah green juga dipakai dalam partai politik, yaitu green party yang dibentuk untuk memberikan tekanan politik yang lebih

1 Hudriyah Mundzir adalah dosen UPT MKU pada Politeknik Negeri Malang. Korespondensi dengan penulis melalui email : hudriyah.mundzir88@gmail.com 
kuat dalam rangka penyadaran pentingnya lingkungan hidup. Penuangan kebijakan lingkungan hidup (green policy) ke dalam produk perundang-undangan yang juga biasa diterjemahkan ke dalam bahasa Inggris dengan istilah green legislation ${ }^{2}$. Karena itu, jika norma hukum tersebut diadopsikan ke dalam bahasa Inggris dengan green legislation. Karena itu, jika norma hukum tersebut diadopsikan ke dalam teks undang-undang dasar, maka hal itu disebut dengan green constitution. Dalam banyak ulasan, Konstitusi Portigal 1976, Konstitusi Spanyol 1978, Konstitusi Polandia 1997 dan Konstitusi Ekuador 2008 disebut juga dengan green constitution. Konstitusi hijau yang paling baru adalah Konstitusi Perancis yang berubah menjadi hijau tahun 2006 dengan mengadopsikan Charter of Environment of 2004 menjadi bagian dari Preambul UUD Perancis yang berlaku. Demikian pula Konstitusi Ekuador 2008 sangat hijau warnanya, dalam arti sangat tegas dan kuat memberikan perlindungan kepada lingkungan hidup.

Arah kebijakan green constitution yang selanjutnya dalam tulisan ini ditulis dengan konstitusi hijau tercermin dalam environmental oriented law yaitu Undang-Undang Nomor 32 Tahun 2009 tentang Perlindungan dan Pengelolaan Lingkungan Hidup (yang disingkat dengan UUPLH) yang memayungi undang-undang yang berkaitan dengan perlindungan lingungan seperti undang-undang kehutanan, undang-undang pertambangan, undang-undang sumber daya alam, dan undang-undang perlindungan lingkungan lainnya. Dengan demikian UUPLH disebut sebagai "umbrella act" atau "umbrella provision"”.

Perlindungan dan pengelolaan lingkungan hidup adalah bentuk penjaminan hak asasi lingkungan yang merupakan perwujudan pembangunan berkelanjutan Indonesia. Karena Indonesia adalah merupakan salah satu negara di dunia yang mempunyai banyak sumber daya alam (natural resources). Sumber daya alam itu ada yang dapat diperbaharui (renewable), dan ada juga yang tidak dapat diperbaharui (renewable). Sumber daya alam yang tidak dapat diperbaharui adalah seperti emas, tembaga, perak, batubara, intan, nikel, mangan, dan lain sebagainya. Sedangkan sumber daya alam yang dapat diperbaharui adalah seperti air, tumbuhan dan lain sebagainya ${ }^{4}$.

Sumber daya alam yang tidak dapat diperbaharui (unrenewable) adalah merupakan salah satu aset yang dimiliki oleh Indonesia yang memiliki nilai komersil bagi pemerintah Indonesia. Untuk meningkatkan nilai komersil sumber daya alam yang tidak dapat diperbaharui (unrenewable), pemerintah Indonesia melakukan pertambangan yang dikonstruksikan sebagai suatu kegiatan. Pertambangan adalah sebagian atau seluruh tahapan kegiatan dalam rangka penelitian, pengelolaan, dan pengusahaan mineral atau batubara yang meliputi penyelidikan umum, eksplorasi, studi kelayakan, konstruksi, penambangan, pengolahan dan pemurnian, pengangkutan dan penjualan,

2 Jimly Asshiddiqie, 2009, Green Constitution Nuansa Hijau Undang-Undang Dasar Negara Republik Indonesia 1945, Jakarta: PT RajaGrafindo Persada, h. 4.

3 M. Hadin Muhjad, Hukum Lingkungan Sebuah Pengantar untuk Konteks Indonesia, Yogyakarta: Genta Publishing, 2015, h. 5.

4 Seperti yang ditulis dalam paper I Nyoman Nurjaya di The International Seminar in Environmental Law Development and Reform of Asian Countries, Canada, and Australia: A Comparative Perspective pada tanggal 25-27 Februari 2010 di Malang h. 1. 
serta kegiatan pasca tambang. Jadi kegiatan dalam pertambangan itu meliputi (1) Penelitian, (2) Pengelolaan, dan (3) Pengusahaan5 .

Kegiatan pertambangan adalah merupakan salah satu pemanfaatan sumber daya alam yang dilakukan untuk pencapaian pertumbuhan ekonomi. Pemanfaatan sumber daya alam pada kenyataannya dilakukan tanpa memperhatikan prinsip-prinsip keadilan, demokratis, dan keberlanjutan fungsi sumber daya alam. Sehingga secara perlahan dan pasti menimbulkan kerusakan dan degradasi kuantitas maupun kualitas sumber daya alam ${ }^{6}$. Setiap pengelolan dan penggunaan sumber daya nasional bertujuan untuk sebesar-besar kemakmuran rakyat. Tujuan ini dipandang sebagai kepentingan yang tidak dapat diabaikan, sebab selain merupakan amanat konstitusi, juga didambakan oleh setiap warganegara dan menjadi tanggung jawab negara sebagai konsekuensi dari hak menguasai negara itu sendiri. Oleh karena itu setiap pengusahaan dan penggunaan sumber daya alam disesuaikan dengan tujuan (doelmatig) ${ }^{7}$.

Sistem pengelolaan pertambangan di Indonesia masih bersifat pluralistik. Hal ini disebabkan beraneka ragam kontrak atau izin pertambangan yang berlaku saat ini dalam kegiatan pertambangan. Ada kontrak atau izin pertambangan yang berlaku didasarkan pada UndangUndang Nomor 11 Tahun 1967 tentang Ketentua-Ketentuan Pokok Pertambangan dan ada izin yang diberlakukan berdasarkan Undang-Undang Nomor 4 Tahun 2009 tentang Pertambangan Mineral dan Batubara.

Salah satu perubahan yang mendasar dalam Undang-Undang Nomor 4 Tahun 2009 adalah perubahan sistem pengusahaan pertambangan mineral dan batubara. Dalam Undang-Undang Nomor 11 Tahun 1967 menggunakan sistem kontrak dalam pengusahaan pertambangan mineral dan batubara. Baik kontrak karya maupun perjanjian karya pengusahaan pertambangan batubara (PKP2B). Sedangkan Undang-Undang Nomor 4 Tahun 2009 menggunakan izin. Izin yang diberikan kepada pemohon meliputi Izin Usaha Pertambangan (IUP), Izin Pertambangan Rakyat (IPR), dan Izin Usaha Pertambangan Khusus (IUPK). Dalam Pasal 1 angka 7 UndangUndang Nomor 4 Tahun 2009. Dasar hukum Undang-Undang Pertambangan Mineral dan Batubara adalah untuk memberikan perlindungan terhadap sumber daya alam Indonesia.

Pada bulan Januari 2014, pemerintah mengeluarkan Peraturan Pemerintah Nomor 1 Tahun 2014 yang menyatakan bahwa perusahaan tambang yang belum mempunyai smelter dilarang untuk melakukan ekspor produk mereka yang mengakibatkan efek domino dalam dunia pertambangan dan dunia bisnis yang berkaitan dengan kegiatan pertambangan. Banyak perusahaan tambang yang terpaksa melakukan pemutusan hubungan kerja secara besar-besaran terhadap pegawainya, seperti operator dan tenaga kontrak lainnya. Perusahaan-perusahaan yang terkait

5 Salim HS, 2012, Hukum Pertambangan Mineral dan Batubara, Jakarta: Sinar Grafika, h. 15.

6 I Nyoman Nurjaya, 2006, Pengelolaan Sumber Daya Alam dalam Perspektif Antropologi Hukum, Malang: kerjasama Program Magister Ilmu Hukum Program Pascasarjana Unibraw, ARENA HUKUM Majalah Fakultas Hukum Universitas Brawijaya dengan PENERBIT UNIVERSITAS NEGERI MALANG, h. 47.

7 dah Dwi Qrbani, Politik Hukum Pengelolaan Minyak Bumi dan Gas Bumi di Indonesia, Jurnal Arena Hukum Fakultas Hukum Universitas Brawijaya, Volume 6 Nomor 2 Agustus 2012, h. 120. 
dengan dunia pertambangan seperti perusahaan persewaan mobil, persewaan alat berat, persewaan kapal dan lain sebagainya juga menerima dampaknya.

\subsection{Metodelogi Penelitian}

Penelitian ini dilakukan untuk mengkaji implikasi kebijakan-kebijakan tentang perlindungan dan pengelolaan lingkungan hidup dan pertambangan mineral dan batbara, dan mencoba untuk merumuskan politik hukum yang mewujudkan green constitution. Penelitian ini menggunakan metode penelitian hukum normatif ${ }^{8}$, yaitu dengan meneliti pada data sekunder bidang hukum yang ada sebagai data kepustakaan dengan menggunakan metode berpikir deduktif dan kriterium kebenaran koheren. Sifat penelitian yang digunakan dalam penelitian ini dilakukan secara deskriptif analitis, yaitu menggambarkan hal-hal yang berkaitan dengan hukum pertambangan, Asas-asas Hukum pertambangan secara menyeluruh dan sistematis, selanjutnya terhadap permasalahan yang timbul dilakukan analisis dengan menggunakan interpretasi/penafsiran hukum. Penelitian ini dilakukan dengan menggunakan pendekatan penelitian konseptual (concepttual approach $)^{9}$.

\section{HASIL DAN PEMBAHASAN}

\subsection{Pengertian Dan Karakteristik Hukum Pertambangan Mineral Dan Batubara}

Dalam dunia pertambangan, Indonesia memang dikenal sebagai negara yang kaya dengan kandungan mineral yang siap diangkat kapan saja. Sehingga hukum pertambangan merupakan salah satu bidang kajian hukum yang mengalami perkembangan yang sangat pesat di Indonesia. Hal ini dibuktikan dengan ditetapkannya berbagai peraturan perundang-undangan yang mengatur tentang pertambangan ${ }^{10}$. Pada dekade tahun 1960-an, undang-undang yang mengatur tentang pertambangan, yaitu Undang-Undang Nomor 11 Tahun 1967 tentang Ketentuan-Ketentuan Pokok Pertambangan, sementara pada dekade tahun 2000 atau khususnya pada tahun 2009, maka Pemerintah dengan persetujuan DPR RI telah menetapkan Undang-Undang Nomor 4 Tahun 2009 tentang Pertambangan Mineral dan Batubara.

Menurut Salim dalam bukunya yang berjudul Hukum Pertambangan Mineral dan Batubara istilah hukum pertambangan berasal dari terjemahan bahasa Inggris, yaitu mining law, bahasa Belanda disebut mijnreght, sedangkan dalam bahasa Jerman disebut dengan bergrecht. Johan Kuyek mengemukakan pengertian hukum pertambangan.

Mining law is:

"have been set up to protect the interests of the mining industry and to minimize the conflicts between mining companies by giving clarity to who owns what rights to mine. They were never intended to control mining or its impact on land or people. We have to look to other laws to protect these interest"

\footnotetext{
8 Soerjono Soekanto \& Sri Mamudji, 1985, Penelitian Hukum Normatif, Jakarta: Rajawali, h. 15.

9 Peter Mahmud Marzuki, 2005, Penelitian Hukum, Jakarta: Kencana, h. 137.

${ }^{10}$ Gatot Supramono, 2012, Hukum Pertambangan Mineral dan Batubara di Indonesia. Jakarta: Rineka Cipta, h. 1.
} 
Artinya: hukum pertambangan merupakan seperangkat aturan yang bertujuan melindungi kepentingan yang berkaitan dengan industri pertambangan dan untuk meminimalkan konflik antara perusahaan tambang dan memberikan penjelasan yang bersifat umum kepada siapa saja yang mempunyai hak-hak untuk melakukan kegiatan pertambangan. Mereka tidak pernah bermaksud untuk mengendalikan kegiatan pertambangan atau dampaknya terhadap tanah atau orang. Kita harus melihat hukum untuk melindungi kepentingan-kepentingan yang berkaitan dengan pertambangan.

Sehingga dari definisi ini dapat dianalisa tujuan hukum pertambangan. Tujuan hukum pertambangan, yaitu melindungi kepentingan yang berkaitan dengan industri pertambangan, mencegah atau meminimalkan konflik antara perusahaan tambang dengan masyarakat yang berada di wilayah pertambangan.

Definisi lain tentang hukum pertambangan disajikan oleh Salim $\mathrm{HS}^{11}$ yang mengemukakan bahwa hukum pertambangan adalah:

" keseluruhan kaidah-kaidah hukum yang mengatur kewenangan Negara dalam pengelolaan bahan galian (tambang) dan mengatur hubungan hukum antara Negara dengan orang dan atau badan hukum dalam pengelolaan dan pemanfaatan bahan galian (tambang)"

Istilah hukum pertambangan mineral dan batubara berasal dari terjemahan bahasa Inggris, yaitu mineral and coal mining law, bahasa Belanda disebut dengan mineraal-en kolenmijnen recht atau bahasa Jerman disebut dengan istilah mineral und kohlebergbau gesetz. Ada empat unsur yang terkandung dalam Hukum Pertambangan Mineral dan Batubara, yaitu hukum, pertambangan, mineral, dan batubara.

Hukum diartikan sebagai aturan yang mengatur hubungan antara Negara dengan rakyat, antara manusia dengan manusia dan hubungan antara manusia dengan lingkungannya. Pertambangan adalah:

"Sebagian atau seluruh tahapan kegiatan dalam rangka penelitian, pengeloalaan dan pengusahaan mineral atau batubara yang meliputi penyelidikan umum, eksplorasi, study kelayakan, konstruksi, penambangan, pengolahan dan pemurnian, pengangkutan dan penjualan, serta kegiatan pascatambang".

Dalam definisi ini, pertambangan dikonstruksikan sebagai suatu kegiatan. Kegiatan itu, meliputi (1) penelitian, (2) pengelolan, dan (3) pengusahaan. Mineral merupakan senyawa anorganik yang terbentukdi alam. Dari unsur-unsur di atas, dapat dirumuskan definisi hukum pertambangan mineral dan batubara. Hukum pertambangan mineral dan batubara merupakan:

"kaidah hukum yang mengatur hubungan antara Negara dengan mineral dan batubara dan mengatur hubungan antara Negara dengan subjek hukum, baik bersifat perorangan maupun badan hukum dalam rangka pengusahaan mineral dan batubara".

11 Salim HS, 2010, Hukum Pertambangan di Indonesia,Jakarta: Rajawali Pers, h. 8. 
Ada dua macam hubungan yang diatur dalam hukum pertambangan mineral dan batubara, yaitu:

1. Mengatur hubungan antara Negara dengan mineral dan batubara; dan

2. Mengatur hubungan antara Negara dengan subjek hukum.

Hubungan antara Negara dengan bahan mineral dan batubara adalah Negara mempunyai kewenangan untuk mengatur pengelolaan mineral dan batubara. Ujud peraturannya, yaitu Negara membuat dan menetapkan berbagai peraturan perundang-undangan yang berkaitan dengan mineral dan batubara. Salah satu undang-undang yang ditetapkan oleh Pemerintah dengan persetujuan DPR, yaitu undang-undang Nomor 4 Tahun 2009 tentang Pertambangan Mineral dan Batubara dan berbagai peraturan pelaksanaannya. Landasan filosofis atau pertimbangan hukum ditetapkan Undang-Undang Nomor 4 Tahun 2009 tentang Pertambangan Mineral dan Batubara, yaitu bahwa:

“ Mineral dan batubarayang terkandung dalam wilayah hukum pertambangan Indonesia merupakan kekayaan alam tak terbarukan sebagai karunia Tuhan Yang Maha Esa yang mempunyai peranan penting dalam memenuhi hajat hidup orang banyak, karena itu pengelolaannya harus dikuasai oleh Negara untuk memberi nilai tambah secara nyata bagi perekonomia nasional dalam usaha mencapai kemakmuran dan kesejahteraan rakyat secara berkeadilan".

Ada tiga unsur esensial yang tercantum dalam landasan filosofis atau pertimbangan hukum Undang-Undang Nomor 4 Tahun 2009, yaitu eksistensi sumberdaya mineral dan batubara, penguasaan negara, dan tujuan penguasaan Negara. Di Indonesia, Negara diberi kewenangan untuk menguasai sumber daya mineral dan batubara. Makna penguasaan Negara ${ }^{12}$ ialah:

“Negara mempunyai kebebasan atau kewenangan penuh (vooldige bovoegdheid)untuk menentukan kebijaksanaan yang diperlukan dalam bentuk mengatur (regelen), mengurus (besturen) dan mengawasi (toezichthouden) penggunaan dan pemanfaatan sumber daya alam nasional".

Rumusan penguasaan Negara juga ditemukan dalam Putusan Mahkamah Konstitusi Republik Indonesia Nomor 002/PUU-1/2003 halaman 208-209, yang berbunyi:

"Pengertian "dikuasai oleh negara" haruslah diartikan mencakup makna penguasaan oleh Negara dalam arti luas yang bersumber dan diturunkan dari konsepsi kedaulatan rakyat Indonesia atas segala sumber kekayaan "bumi, air dan alam yang terkandungdi dalamnya".

Termasuk pula di dalamnya pengertian kepemilikan publik oleh kolektivitas rakyat atas sumber-sumber kekayaan dimaksud. Rakyat secara kolektif itu dikonstruksikan oleh UUD 1945 memberikan mandate kepada Negara untuk mengadakan kebijakan (beleid) dan tindakan pengurusan (bestuursdaad), pengaturan (regelendaad), pengelolaan (beheersdaad), dan pengawasan

12 Abrar Saleng, 2004, Hukum Pertambangan, Yogyakarta: UII Press, h. 219. 
(toezichthoudensdaad) untuk tujuan sebesar-besarnyakemakmuran rakyat". Kewenangan Negara dalam putusan ini, meliputi membuat kebijakan (beleid) dan pengurusan (bestuursdaad), pengaturan (regelendaad), pengelolaan (beheersdaad), dan pengawasan (toezichthoudensdaad).

Fungsi kepengurusan (bestuursdaad) oleh Negara dilajukan oleh pemerintah dengan kewenangan untuk mengeluarkan dan mencabut fasilitas perijinan (vergunning), lisensi (lisentie), dan konsesi (consessie). Fungsi pengaturan oleh Negara (regelendaad) dilakukan melalui kewenangan oleh legislasi oleh DPR bersama pemerintah, dan regulasi oleh pemerintah. Fungsi Pengelolaan (beheersdaad) dilakukan melalui mekanisme pemilikan saham (share-holding) dan/ atau melalui keterlibatan langsung dalam manajemen Badan Usaha Milik Negara atau Badan Hukum Milik Negara sebagai instrumen kelembagaan, yang melaluinya Negara, c.q. pemerintah, mendayagunakan penguasaannya atas sumber-sumber kekayaan itu untuk digunakan lagi sebesar-besarnya kemakmuran rakyat. Demikian pula fungsi pengawasan oleh Negara (toezichthoudensdaad) dilakukan oleh Negara, c.q. pemerintahdalam rangka mengawasi dan mengendalikan agar pelaksanaan penguasaan oleh Negara atas sumber-sumber kekayaan dimaksud benar-benar dilakukan untuk sebesar-besarnya kemakmuran seluruh rakyat.

Pada hakikatnya, tujuan penguasaan Negara atas sumber daya alam adalah memberi nilai tambah secara nyata bagi perekonomian nasional dalam usaha mencapai kemakmuran dan kesejahteraan rakyat secara berkeadilan. Sementara itu, yang menjadi tujuan pengelolaan mineral dan batubara itu, yaitu menjamin efektivitas pelaksanaan dan pengendalian kegiatan usaha pertambangan secara berdaya guna, berhasil guna dan berdaya saing, menjamin manfaat pertambangan mineral dan batubara secara berkelanjutan dan berwawasan lingkungan hidup, menjamin tersedianya mineral dan batubara sebagai bahan baku dan/atau sebagai sumber energi untuk kebutuhan dalam negeri, mendukung dan menumbuhkembangkan kemampuan nasional agar lebih mampu bersaing di tingkat nasional, regional dan internasional, meningkatkan pendapatan masyarakat lokal, daerah, dan negara serta menciptakan lapangan kerja untuk sebesar-besarnya kesejahteraan rakyat, dan menjamin kepastian hukum dalam penyelenggaraan kegiatan usaha pertambangan mineral dan batubara.

Di negara-negara seperti Philipina, Ghana, dan China, negara mempunyai kedudukan yang sangat penting dalam pengelolaan dan penguasaan sumber daya alam. Karena negara sebagai pemilik sumber daya alam mineral atau tambang.Unsur yang kedua hukum pertambangan mineral dan batubara yaitu mengatur hubungan antara negara dengan subjek hukum. Kegiatan pertambangan mineral dan batubara tidak hanya dilakukan oleh Negara, namun Negara dapat memberikan ijin kepada subjek hukum untuk melakukan kegiatan pertambangan mineral dan batubara. Subjek hukum, yaitu pendukung dan kewajiban, subjek hukum dibagi menjadi dua macam, yaitu manusia dan badan hukum. Subjek hukum yang diberi hak untuk melakukan kegiatan pertambangan mineral dan batubara, meliputi (1) orang dan (2) badan usaha. Badan usaha dapat berbadan hukum dan tidak berbadan hukum. Badan hukum meliputi PT, Koperasi, Yayasan, BUMN, dan BUMD. Sedangkan badan usaha yang tidak berbadan hukum meliputi CV dan firma. 
Karakteristik hukum pertambangan mineral dan batubara merupakan kaidah hukum yang bersifat khusus. Dikatakan khusus, oleh karena objeknya khusus dan sifat hubungan para pihak bersifat administratif. Yang menjadi objek kajian hukum pertambangan mineral dan batubara hanya berkaitan dengan pertambangan mineral dan batubara. Pertambangan mineral adalah pertambangan kumpulan mineral yang berupa bijih atau batuan. Bijih adalah "sekumpulan mineral yang dari padanya dapat dihasilkan satu atau lebih logam secara ekonomis sesuai dengan keadaan teknologi dan lingkungan pada saat itu". Pertambangan batubara adalah pertambangan endapan karbon yang terdapat di dalam bumi, termasuk bitumen padat, gambut dan batuan aspal.

Dalam pasal 2 Undang-Undang Nomor 4 Tahun 2009 tentang Pertambangan Mineral dan Batubara telah ditentukan asas-asas hukum pertambangan mineral dan batubara. Ada tujuh asas hukum pertambangan mineral dan batubara. Ketujuh asas itu, meliputi manfaat, keadilan, keseimbangan, keberpihakan kepada kepentingan bangsa, partisipatif, transparansi dan akuntabilitas, dan berkelanjutan dan berwawasan lingkungan.

Asas manfaat merupakan asas dimana di dalam pengelolaan sumber daya mineral dan batubara dapat memberikan kegunaan bagi kesejahteraan masyarakat banyak. Asas ini sesuai dengan konsep yang dikembangkan Jeremy Bentham. Menurut Friedmann dalam legal theory hukum harus memberikan manfaat atau kegunaan bagi orang banyak. Konsep utilityyang dikembangkan oleh Jeremy adalah dimaksudkan untuk menjelaskan konsep kebahagiaan atau kesejahteraan. Sesuatu yang dapat menimbulkan kebahagiaan ekstra adalah sesuatu yang baik. Sebaliknya, sesuatu yang menimbulkan sakit adalah buruk. Aksi-aksi pemerintahan harus selalu diarahkan untuk meningkatkan kebahagiaan sebanyak mungkin orang (the Greates happiness principle).

Asas keadilan merupakan asas dalam pengelolaan dan pemanfaatan mineral dan batubara dimana di dalam pemanfaatan itu harus memberikan hak yang sama rasa dan rata bagi masyarakat banyak. Masyarakat dapat diberikan hak untuk mengelola dan memanfaatkan mineral dan batubara, dan juga dibebani kewajiban untuk menjaga kelestarian lingkungan hidup. Selama ini, masyarakat kurang mendapat perhatian karena pemerintah selalu memberikan hak istimewa kepada perusahan-perusahaan besar dalam mengelola sumber daya mineral dan batubara.

Asas keseimbangan adalah suatu asas yang menghendaki bahwa dalam pelaksanaan pertambangan mineral dan batubara harus mempunyai kedudukan hak dan kewajiban yang setara dan seimbang antara pemberi izin dengan pemegang izin. Pemberi izin dapat menuntut hak -haknya kepada pemeggang izin, apakah itu IPR, IUP maupun IUPK. Begitu juga pemegang izin dapat menuntut haknya kepada pemberi izin supaya pemberi izin dapat melaksanakan kewajibannya, seperti memberikan pembinaan dan pengawasan terhadap pemegang izin. Ini berarti keseimbangan dalam hak dan kewajiban.

Asas keberpihakan kepada kepentingan bangsa adalah asas bahwa dalam pelaksanaan pertambangan mineral dan batubara, bahwa pemerintah, baik pemerintah pusat maupun pemerintah daerah harus memihak atau pro kepada kepentingan bangsa yang lebih besar. Ini berarti bahwa 
kepentingan bangsa yang harus diutamakan dibandingkan dengan kepentingan dari para investor. Namun, demikian pemerintah juga harus memperhatikan kepentingan investor.

Asas partisipatif merupakan asas bahwa dalam pelaksanaan pertambangan mineral dan batubara, tidak hanya peran serta pemberi dan pemegang izin semata-mata, namun masyarakat, terutama masyarakat yang berada di lingkar tambang harus ikut berperan serta dalam pelaksanaan kegiatan tambang. Wujud peran serta masyarakat, yaitu masyarakat dapat ikut bekerja pada perusahaan tambang, dapat menjadi pengusaha maupun distributor.

Asas transparansi, yaitu asas bahwa dalam pelaksanaan pertambangan mineral dan batubara harus dilakukan secara terbuka. Artinya, setiap informasi yang disampaikan kepada masyarakat oleh pemberi dan pemegang izin harus disosialisasikan secara jelas dan terbuka kepada masyarakat, misalnya tentang tahap-tahap kegiatan pertambangan kebutuhan tenaga kerja, dan lainnya.

Asas akuntabilitas, yaitu setiap kegiatan pertambangan mineral dan batubara harus dapat dipertanggungjawabkan kepada rakyat dengan memperhatikan rasa keadilan dan kepatutan. Asas akuntabilitas ini erat kaitannya dengan hak-hak yang akan diterima oleh pemerintah, baik pemerintah pusat maupun daerah yang bersumber dari kegiatan-kegiatan pertambangan mineral dan batubara. Misalnya, pemegang IUPK memberikan keuntungan kepada pemerintah daerah sebesar $1 \%$, maka penggunaan uang tersebut harus dapat dipertanggungjawabkan kepada rakyat, dalam hal ini adalah DPRD, baik kabupaten/ kota maupun provinsi.

Asas berkelanjutan dan berwawasan lingkungan adalah asas yang secara terencana mengintegrasikan dimensi ekonomi, lingkungan dan sosial budaya dalam keseluruhan usaha pertambangan mineral dan batubara untuk mewujudkan kesejahteraan masa kini dan masa mendatang.

\subsection{Implikasi Undang-Undang Nomor 4 Tahun 2009 Tentang Pertambangan Mineral Dan Batubara}

Seperti yang telah kita ketahu Indonesia adalah merupakan salah satu negara di dunia yang mempunyai banyak sumber daya alam (natural resources). Sumber daya alam itu ada yang dapat diperbaharui (renewable), dan ada juga yang tidak dapat diperbaharui (renewable). Sumber daya alam yang tidak dapat diperbaharui adalah seperti emas, tembaga, perak, batubara, intan, nikel, mangan, dan lain sebagainya. Sedangkan sumber daya alam yang dapat diperbaharui adalah seperti air, tumbuhan dan lain sebagainya. Sumber daya alam yang tidak dapat diperbaharui (unrenewable) adalah merupakan salah satu aset yang dimiliki oleh Indonesia yang memiliki nilai komersil bagi pemerintah Indonesia. Untuk meningkatkan nilai komersil sumber daya alam yang tidak dapat diperbaharui (unrenewable), pemerintah Indonesia melakukan pertambangan yang dikonstruksikan sebagai suatu kegiatan.

Pada dasarnya setiap aturan itu dirumuskan untuk mengatur segala sesuatu agar menjadi lebih baik dan teratur. Begitu juga dengan Undang-Ungang Nomor 4 tahun 2004 tentang Pertambangan 
Mineral dan Batubara. Tujuan undang-undang tersebut adalah melindungi kepentingan yang berkaitan dengan industri pertambangan dan mencegah atau meminimalkan konflik antara perusahaan tambang dengan masyarakat yang berada di wilayah pertambangan. Kebijakan pelarangan ekspor bahan mentah sudah berdasarkan pada ketujuh asas tersebut. Pelarangan tersebut memberikan manfaat bagi para pihak yaitu pengusaha tambang dan negara. Karena akan menaikkan nilai ekspor bahan tambang mentah Indonesia. Nilai ekspor bahan tambang mentah jauh lebih rendah dibanding nilai ekspor bahan tambang antara (bahan tambang antara adalah hasil tambang yang sudah dimurnikan dan diolah). Kebijakan pelarangan itu juga sudah adil dan seimbang ditinjau dari berbagai pihak yang terkait (stakeholder). Ditinjau dari negara, negara juga akan menerima pemasukan dengan adanya kenaikan nilai ekspor bahan tambang. Perusahaan pertambangan sendiri juga akan termotivasi untuk melakukan pemurnian dan pengolahan bahan tambang mentah menjadi bahan tambang yang merupakan "antara" atau bahan tambang yang siap pakai. Pada kebijakan pelarangan ekspor bahan tambang mentah juga sudah melaksanakan asas keberpihakan. Karena kebijakan tersebut untuk membela kepentingan bangsa. Asas keberpihakan adalah asas bahwa dalam pelaksanaan pertambangan mineral dan batubara, bahwa pemerintah, baik pemerintah pusat maupun pemerintah daerah harus memihak atau pro kepada kepentingan bangsa yang lebih besar. Ini berarti bahwa kepentingan bangsa yang harus diutamakan dibandingkan dengan kepentingan dari para investor. Namun, demikian pemerintah juga harus memperhatikan kepentingan investor.

Pelaksanaan asas partisipatif dalam pertambangan mineral dan batubara, tidak hanya peran serta pemberi dan pemegang izin semata-mata, namun masyarakat, terutama masyarakat yang berada di lingkar tambang harus ikut berperan serta dalam pelaksanaan kegiatan tambang. Wujud peran serta masyarakat, yaitu masyarakat dapat ikut bekerja pada perusahaan tambang, dapat menjadi pengusaha maupun distributor. Asas transparansi, menggariskan bahwa dalam pelaksanaan pertambangan mineral dan batubara harus dilakukan secara terbuka. Artinya, setiap informasi yang disampaikan kepada masyarakat oleh pemberi dan pemegang izin harus disosialisasikan secara jelas dan terbuka kepada masyarakat, misalnya tentang tahaptahap kegiatan pertambangan kebutuhan tenaga kerja, dan lainnya.

Kegiatan pertambangan mineral dan batubara harus dapat dipertanggungjawabkan kepada rakyat dengan memperhatikan rasa keadilan dan kepatutan. Asas akuntabilitas ini erat kaitannya dengan hak-hak yang akan diterima oleh pemerintah, baik pemerintah pusat maupun daerah yang bersumber dari kegiatan-kegiatan pertambangan mineral dan batubara. Misalnya, pemegang IUPK memberikan keuntungan kepada pemerintah daerah sebesar 1\%, maka penggunaan uang tersebut harus dapat dipertanggungjawabkan kepada rakyat, dalam hal ini adalah DPRD, baik kabupaten/ kota maupun provinsi. Pelaksanaan dari asas berkelanjutan dan berwawasan lingkungan adalah asas yang secara terencana mengintegrasikan dimensi ekonomi, lingkungan dan sosial budaya dalam keseluruhan usaha pertambangan mineral dan batubara untuk mewujudkan kesejahteraan masa kini dan masa mendatang. Jadi kebijakan pelarangan ekspor bahan tambang mineral mentah pada dasarnya sudah mengacu pada asas-asas pertambangan mineral dan batubara, dan sudah ada pemberian toleransi oleh pemerintah kepada perusahaan pertambangan untuk melaksanakan 
Undang-Undang Nomor 4 tahun 2009 tentang Pertambangan Mineral dan Batubara. Meskipun demikian, dalam pelaksanaan kebijakan pelarangan tersebut, menimbulkan berbagai macam dampak bagi berbagai pihak.

Dengan adanya kebijakan pemerintah pusat yang melarang ekspor bahan tambang mentah pada dasarnya bertujuan baik untuk memperbaiki industri dalam negeri. Karena dengan adanya pelarangan bahan tambang mentah akan mendatangkan keuntungan yang jauh lebih besar dibanding mengekspor bahan mentah. Karena nilai ekspor bahan mentah jauh lebih rendah dibanding ekspor bahan tambang mentah yang sudah diolah (pengolahan dan pemurnian oleh smelter). Pelarangan ini bertujuan menjaga kepentingan nasional dan menjamin pasokan bahan baku untuk industri dalam negeri serta melindungi sumber daya alam yang dimiliki oleh negara Indonesia yang berupa bahan tambang yang merupakan sumber daya alam yang tidak dapat diperbaharui. Sehingga harus diberikan perlindungan oleh pemerintah.

Berkaitan dengan implikasi Undang-Undang Pertambangan Mineral dan Batubara, Kementerian Energi dan Sumber Daya Mineral telah mencatat sebanyak 185 perusahaan telah mengajukan izin pembangunan fasilitas pengolahan dan pemurnian (smelter) mineral di Indonesia. Rudi Rubiandini, Wakil Menteri Energi menuturkan proposal pembangunan smelter meningkat pasca diterapkan Peraturan Menteri Energi dan Sumber Daya Mineral Nomor 7 Tahun 2012 tentang Peningkatan Nilai Tambah Mineral Melalui Kegiatan Pengolahan dan Pemurnian Mineral, sejak 6 Mei lalu ${ }^{13}$.

Undang-Undang Pertambangan Mineral dan Batubara sebagai perwujudan kehendak negara pada dasarnya bertujuan untuk memberi nilai tambah secara nyata bagi perekonomian nasional dalam usaha mencapai kemakmuran dan kesejahteraan rakyat secara berkeadilan dan pengelolaan lingkungan hidup yang berkelanjutan untuk mewujudkan kedaulatan lingkungan.

Meskipun negara bertujuan untuk memberi tambah perekonomian nasional dengan pelarangan ekspor tersebut, namun tetap membawa dampak. Dampak akibat dari pelarangan tersebut dirasakan oleh berbagai pihak. Di Sulawesi Tenggara terdapat 19 (Sembilan Belas) perusahaan tambang yang terpaksa berhenti beroperasi menyusul kebijakan pemerintah yang menerapkan Undang-Undang Nomor 4 Tahun 2009 tentang Pertambangan Mineral dan Batubara yang mengeluarkan kebijakan larangan eskpor Mineral dan Batubara dalam bentuk bahan tambang mentah. ${ }^{14}$

\subsection{Politik Hukum Pertambangan Untuk Menciptakan Green Constitution}

Penulis menggulirkan wacana ecocracy sebagai kedaulatan lingkungan hidup untuk menciptakan green constitution. Ecocracy adalah ekosistem dimana suatu pemerintahan mendasarkan kepemerintahannya secara taat asas pada prinsip-prinsip pembangunan berkelanjutan yang

\footnotetext{
13 http://www.satyayudha.com/185-perusahaan-ajukan-izin-bangun-smelter/, diunduh tanggal 21 September 2014.

${ }^{14} \mathrm{http}$ ///sinarharapan.co/news/read/32590/19-perusahaan-tambang-berhenti-beroperasi-di-sultra, diunduh 21 September 
berwawasan lingkungan (ecologically sustainable development). Sehingga konstitusionalisasi norma hukum lingkungan menjadi sangat diperlukan untuk memperkuat demokrasi dan negara hukum serta tata pemerintahan yang baik.

Environmental Sustainable Development merupakan tawaran paradigma pembangunan dalam memperkuat ecocracy dengan memperkenalkan orientasi pembangunan yang menekankan pentingnya tiga pilar yang melandasi pembangunan keputusan yaitu Pertumbuhan ekonomi, pembangunan sosial (terutama bagi masyarakat rentan dan marjinal) dan perlindungan daya dukung ekosistem.

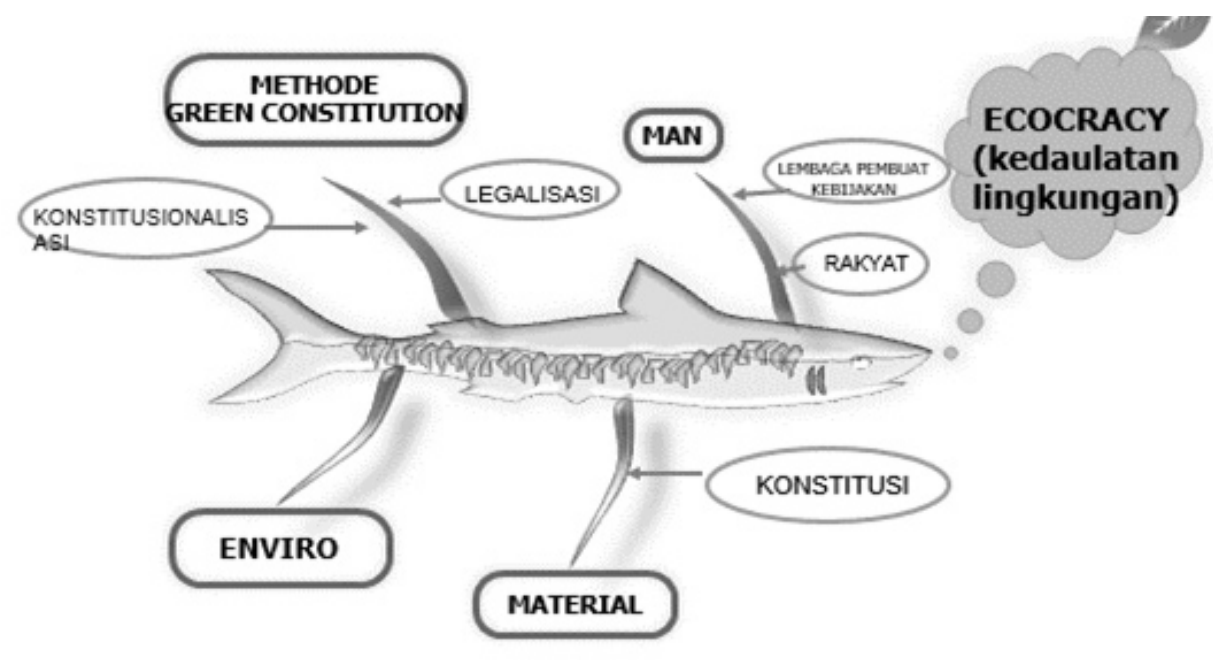

Gambar 1. Konsep Perwujudan Ecocracy

Dari paparan sebelumya konstitusionalisasi norma hukum lingkungan diwujudkan dalam komitmen negara. Beberapa tingkatan komitmen negara, yaitu

1. Kategori Komitmen Tertinggi, pengakuan hak hukum untuk alam (right for nature) yang dilengkapi dengan hak-hak subyektif (subjective rights) dan kewajiban negara (the duty of the state) di bidang pengelolaan lingkungan hidup. Paradigma yang ditawarkan adalah ecocentrisme.

2. Karegori Komitmen Tinggi, pengakuan subjective rights dilengkapi dengan duty of the state di bidang pengelolaan lingkungan hidup serta arah dari pola pembangunan (pembangunan berkelanjutan) dalam kemasan khusus yaitu environmental charter.

3. Kategori Komitmen Memadai, kategori ini memberikan pengakuan subjective rights dan duty of the state di bidang pengelolaan lingkungan hidup dalam pasal-pasal khusus (tidak ditumpangkan atau dicampur dengan hak-hak fundamental yang lain), dan tidak memuat arah atau pola pembangunan.

4. Kategori Komitmen Sedang, kategori ini memberikan pengakuan tentang subjective rights tanpa mengakui secara spesifik duty of the state di bidang pengelolaan lingkungan hidup, namun terdapat muatan tentang pola dan arah pembangunan yang berkelanjutan walaupun tidak ditempatkan dalam pasal khusus dan hanya ditumpangkan dalam hak-hak fundamental lainnya. 
5. Kategori Komitmen Rendah, kategori ini mengacu kepada konstitusi yang sama sekali tidak mengakui norma hukum lingkungan (subjective rights maupun duty of the state) maupun pemuatan pola dan arah pembangunan.

Dari uraian di atas, dapat disimpulkan bahwa sejak meluasnya kesadaran umat manusia akan pentingnya perlindungan lingkungan hidup, kebijakan pemerintahan yang dikembangkan di pelbagai negara di dunia sekarang telah berlangsung dalam dua tahap perkembangan, yaitu gelombang legislasi kebijakan dan konstutusionalisasi kebijakan lingkungan hidup. Kemudian dalam tahap berkembang adanya tiga model ataupun tahap perkembangan lagi, yaitu (a) tahap atau model konstutusionalisasi formal seperti konstutusi Perancis, dan (c) tahap ketiga atau model konstutusionalisasi struktural seperti di Ekuador. Setelah reformasi, UUD 1945 juga telah mengadopsikan prinsip-prinsip pembangunan berkelanjutan dan ketentuan mengenai hak asasi manusia atas lingkungan hidup yang baik dan sehat. UUD 1945 telah melakukan konstutusionalisasi atas kebijakan lingkungan hidup dan prinsip pembangunan yang berkelanjutan, setidaknya konstitusionalisasi formal, sehingga dapat disebut sebagai salah satu konstitusi hijau (green constitution) yang penting disadari dan di tegakkan dalam praktik bernegara.

\section{PENUTUP}

Pelarangan ekspor bahan tambang mentah memiliki dampak positif dan negatif. Dampak positifnya adalah meningkatnya nilai komersil dari bahan tambang tersebut. Di satu sisi menimbulkan dampak negatif yaitu adanya gejolak ekonomi yang besar, seperti banyak perusahaan tambang yang tidak beroperasi, PHK masal, dan lain sebagainya. Rekomendasi yang diberikan adalah dengan pentahapan perkembangan perlindungan lingkungan hidup, yaitu gelombang legislasi kebijakan dan konstutusionalisasi kebijakan lingkungan hidup, pengadopsian prinsipprinsip pembangunan berkelanjutan dan ketentuan mengenai hak asasi manusia atas lingkungan hidup yang baik dan sehat oleh Undang-Undang Dasar Negara Republik Indonesia tahun 1945 dan konstutusionalisasi atas kebijakan lingkungan hidup dan prinsip pembangunan yang berkelanjutan, setidaknya konstutusionalisasi formal, sehingga dapat disebut sebagai salah satu konstitusi hijau (green constitution) yang penting disadari dan di tegakkan dalam praktik bernegara. 


\section{DAFTAR PUSTAKA}

\section{A. Buku}

Abrar Saleng, Hukum Pertambangan, Yogyakarta: UII Press, 2004.

Gatot Supramono. Hukum Pertambangan Mineral dan Batubara di Indonesia. Jakarta: Rineka Cipta, 2012.

Ismail Saleh. Hukum dan Ekonomi. Jakarta: Gramedia Pustaka Utama, 1990.

Jimly Asshiddigie, Green Constitution Nuansa Hijau Undang-Undang Dasar Negara Republik Indonesia 1945, Jakarta: PT RajaGrafindo Persada, 2009.

M. Hadin Muhjad, Hukum Lingkungan Sebuah Pengantar untuk Konteks Indonesia, Yogyakarta: Genta Publishing, 2015.

Peter Mahmud Marzuki. Penelitian Hukum. Jakarta: Kencana, 2005.

Salim HS, Hukum Pertambangan di Indonesia, Jakarta: Rajawali Pers, 2010. . Hukum Pertambangan Mineral dan Batubara. Jakarta : Sinar Grafika, 2012.

Soerjono Soekanto \& Sri Mamudji. Penelitian Hukum Normatif. Jakarta: Rajawali, 1985.

\section{B. Jurnal}

Indah Dwi Qrbani, Politik Hukum Pengelolaan Minyak Bumi dan Gas Bumi di Indonesia, Jurnal Arena Hukum Fakultas Hukum Universitas Brawijaya, Volume 6 Nomor 2 Agustus 2012, halaman 79-154.

\section{Kamus}

Henry Campbell Black. Black's Law Dictionary Sixth Ed.. St. Paul Minn: West Publishing Co. 1990.

Kamus Besar Bahasa Indonesia Edisi Kedua, Jakarta: Balai Pustaka, 1994.

Kamus Besar Bahasa Indonesia, Jakarta: Balai Pustaka, 1994.

\section{Seminar}

Paper I Nyoman Nurjaya di The International Seminar in Environmental Law Development and Reform of Asian Countries, Canada, and Australia: A Comparative Perspective pada tanggal 25-27 Februari 2010 di Malang.

\section{E. Internet}

http://www.satyayudha.com/185-perusahaan-ajukan-izin-bangun-smelter/, diunduh tanggal 21 September 2014. http://sinarharapan.co/news/read/32590/19-perusahaan-tambang-berhenti-beroperasi-di-sultra, diunduh 21 September 2014. 